NBER WORKING PAPER SERIES

\title{
ESTIMATING MANAGEMENT PRACTICE COMPLEMENTARITY BETWEEN DECENTRALIZATION AND PERFORMANCE PAY
}

\author{
Bryan Hong \\ Lorenz Kueng \\ Mu-Jeung Yang \\ Working Paper 20845 \\ http://www.nber.org/papers/w20845 \\ NATIONAL BUREAU OF ECONOMIC RESEARCH \\ 1050 Massachusetts Avenue \\ Cambridge, MA 02138 \\ January 2015
}

We would like to thank Nick Bloom, Chad Syverson, John Van Reenen; seminar participants at Emory University, Harvard Business School, the University of Washington, the NBER Summer Institute; and, in particular, our discussant Raffaella Sadun, for helpful comments. We are also grateful to Ergete Ferede for sharing his residual income progression data. The usual disclaimer applies. The views expressed herein are those of the authors and do not necessarily reflect the views of the National Bureau of Economic Research.

At least one co-author has disclosed a financial relationship of potential relevance for this research. Further information is available online at http://www.nber.org/papers/w20845.ack

NBER working papers are circulated for discussion and comment purposes. They have not been peerreviewed or been subject to the review by the NBER Board of Directors that accompanies official NBER publications.

(C) 2015 by Bryan Hong, Lorenz Kueng, and Mu-Jeung Yang. All rights reserved. Short sections of text, not to exceed two paragraphs, may be quoted without explicit permission provided that full credit, including $(\odot$ notice, is given to the source. 
Estimating Management Practice Complementarity between Decentralization and Performance

Pay

Bryan Hong, Lorenz Kueng, and Mu-Jeung Yang

NBER Working Paper No. 20845

January 2015

JEL No. D2,H32,J33,L2,M1,M5

\section{ABSTRACT}

The existence of complementarity across management practices has been proposed as one potential explanation for the persistence of firm-level productivity differences. However, thus far no conclusive population-level tests of the complementary joint adoption of management practices have been conducted. Using unique detailed data on internal organization, occupational composition, and firm performance for a nationally representative sample of firms in the Canadian economy, we exploit regional variation in income tax progression as an instrument for the adoption of performance pay. We find systematic evidence for the complementarity of performance pay and decentralization of decision-making from principals to employees. Furthermore, in response to the adoption of performance pay, we find a concentration of decision-making at the level of managerial employees, as opposed to a general movement towards more decentralization throughout the organization. Finally, we find that adoption of performance pay is related to other types of organizational restructuring, such as greater use of outsourcing, Total Quality Management, re-engineering, and a reduction in the number of layers in the hierarchy.

Bryan Hong

Ivey Business School

Western University

1255 Western Road

London, ON N6G 0N1

Canada

bhong@ivey.ca

Lorenz Kueng

Kellogg School of Management

Northwestern University

2001 Sheridan Road

Evanston, IL 60208

and NBER

1-kueng@kellogg.northwestern.edu
Mu-Jeung Yang

Department of Economics

University of Washington

Savery Hall, 327

Seattle, WA 98195-3330

mjyang@uw.edu 


\section{Introduction}

A central empirical fact regarding firm heterogeneity is that even within narrowly defined industries, productivity differences across firms are large and persistent; see Baily, Hulten and Campbell (1992), and Syverson (2011). This empirical pattern is also at the heart of the modern analysis of firm heterogeneity in diverse fields, such as industrial organization, macroeconomics, and international trade. Recent empirical evidence suggests that management practices are closely connected to firm productivity. ${ }^{1}$ However, little is known empirically about how different types of management practices interact to influence productivity. Specifically, complementarity among management practices is a potential cause of persistence in firm productivity, since firms need to jointly adopt many complementary practices to reap the full productivity gains from these management practices. However, since the joint adoption of all these practices can be very difficult and costly to implement, lowproductivity firms might have insufficient incentive or capabilities to do so. For this mechanism to potentially explain persistent firm productivity differences, empirical evidence of management practice complementarity must exist. Therefore, we test for the existence of complementary joint adoption of two key management practices at the heart of efficient decision-making in firms: performance pay and the degree of decentralization of decision-making. On the one hand, a vast literature starting out Drucker (1949) and Penrose (1959) has argued that decentralized decision-making is important to promote firm growth, induce an optimal division of labor, and enable the efficient use of decentralized employee information. ${ }^{2}$ On the other hand, creating incentives for efficient decision-making through performance pay has been at the core of principal-agent analysis, as exemplified by Jensen and Meckling (1976) and surveyed in Laffont and Martimort (2002).

Since the seminal work by Milgrom and Roberts (1990), there has been considerable interest in the complementarity of management or organizational practices; see Brynjolfsson and Milgrom (2013). Despite this interest, empirical evidence on the issue has been limited in scope. Two challenges pose significant hurdles to further empirical progress on this topic. First, large sample data on the internal organization of firms and use of management practices is scarce. In fact, the most prominent empirical studies of management practice complementarity are either case studies such as Milgrom and Roberts (1995) or industry studies such as Ichniowski, Shaw and Prennushi (1997) or Kretschmer, Miravete and Pernias (2012). Second, even in datasets that provide larger samples, such as that used by Bloom and Van Reenen (2007), recovering causal estimates of complementarity proved to be difficult since

\footnotetext{
${ }^{1}$ See, for example, Bloom and Van Reenen (2007) and Bloom, Brynjolfsson, Foster, Jarmin, Patnaik, Saporta Eksten and Van Reenen (2014).

${ }^{2}$ For examples, see Aghion and Tirole (1997), Garicano (2000), Bloom, Sadun and Van Reenen (2012).
} 
joint adoption of management practices can be driven by correlation of unobserved adoption costs instead of complementarity; see Athey and Stern (1998).

Using unique establishment and firm-level panel data on management practices, organization, and firm performance that is representative of all business firms in the Canadian economy, we address both these empirical challenges and provide the first large-sample representative evidence on management practice complementarity. ${ }^{3}$ To establish valid inferences regarding complementarity, we address the issues raised by Athey and Stern (1998) using an instrumental variables (IV) strategy. The basic idea is that higher personal income tax progressivity increases the cost of providing high-powered incentives and hence reduces the adoption of performance and can therefore serve as an instrument for performance pay. To understand why, consider performance pay in a standard principal-agent framework, such as Grossman and Hart (1983). In this model, the principal needs to pay the agent a higher wage in states of the world with high output in order to incentivize the agent to exert hidden effort. Since progressive taxation by definition exhibits higher marginal tax rates on higher income, more progressivity will tend to offset the incentive effects of performance pay. In other words, to induce a given level of effort, the firm has to pay the employee over-proportionally more in high output states to counter the effects of tax progressivity.

We find that firms that adopt performance pay for exogenous reasons decentralize more decision-making from business owners and headquarters to employees. This suggests that performance pay and decentralization of control are complements. This result provides empirical evidence complementing a number of theoretical arguments that have thus far provided conflicting predictions about the relation of performance pay and decentralization. Studies such as Prendergast (2002) and Van Den Steen (2010) described mechanisms through which performance pay and decentralization are complements, while Holmstrom and Milgrom (1991), Krishna and Morgan (2008) and Bester and Kremer (2008) provided theories showing that performance pay and decentralization are substitutes. It is worth emphasizing that our results are not a direct test of these models, since it is still possible that there are some industries or firms to which these theories apply. However, we note that our data allows us to characterize the average degree of complementarity between performance pay and decentralization in the entire population of firms, irrespective of industry, size class, exporter status, and other firm and industry characteristics. In this sense, one can interpret our findings as providing evidence on whether these theories apply on average in the population of business firms.

While the complementarity of performance pay and decentralization is of general interest on its own, it does not tell us much about the process of decentralizing

\footnotetext{
3 More than $90 \%$ of businesses in our data are single-establishment firms. Unless noted otherwise, we therefore use the terms "establishment" and "firm" interchangeably, and we include a multi-establishment indicator in all our empirical analysis.
} 
decision-making to employees. This decentralization could take very different forms that are indicative of the manner in which firms induce efficient decision-making. For example, if information of production line workers is crucial, one would expect decisions to be decentralized mostly to non-managerial employees. If, on the other hand, managerial supervision and control is crucial, as suggested for example by Atalay, Hortascu and Syverson (2013), one would expect decision authority to be given to management. Motivated by these different views on the benefits of decentralization, we further analyze decentralization patterns by measuring decision control separately for managerial and non-managerial employees. We find that firms that adopt performance pay for exogenous reasons concentrate control at the management level. That is, although these firms tend to decentralize decision control from headquarters or business owners to employees, they also reallocate decision tasks from non-managerial to managerial employees. Compatible with this concentration of control at the manager level, we find that these firms have systematically higher hiring rates for managers but not significantly higher overall hiring or firing rates. In other words, not only are decision responsibilities concentrated at the management level, but firms also hire more managers to deal with these responsibilities. Therefore, our findings support the hypothesis advanced by Atalay et al. (2013) that the nature of firms is intimately connected to their role in "mediating managerial supervision and control."

To explore whether unobserved regional factors drive our results, we compare establishments within the same location, which are part of multi-province firms. We show that establishments of firms with headquarters located in regions with high tax progression are less likely to adopt performance pay than establishments in the same location that have headquarters in low tax-progression regions. Furthermore, we find that for these multi-province firms, the same patterns apply as in the general firm population: establishments which adopt performance pay for exogenous reasons decentralize decision-making from principals to employees and reallocate decision tasks from non-managerial to managerial employees.

To obtain a more general understanding of how performance pay influences management practices, we also consider the impact of performance pay adoption on other organizational changes, exploiting the panel dimension of our data. We highlight three findings applying to firms that adopt performance pay. First, these firms systematically pursue business process "re-engineering." In other words, they seek to increase the efficiency of business processes, for example by removing activities without much value added. Despite claims to the contrary, we find that firms which seek to re-engineer their business processes do this without necessarily downsizing their workforce. Second, these firms are more likely to adopt organization-wide programs to ensure a high level of product quality, such as Total Quality Management (TQM). Third, these firms are more likely to reduce the number of managerial layers (de-layering). These results in turn have important implications for theories of 
business processes and models of endogenous management layers.

The remainder of the paper is organized in the following manner. Section 2 develops a baseline theory that illustrates the incentive trade-offs that make decentralization and performance pay either complements or substitutes and guides our empirical analysis. Section 3 describes our establishment- and firm-level data. Section 4 describes our IV strategy and discusses our baseline empirical results. Section 5 provides a number of robustness checks, and section 6 concludes our analysis.

\section{Related Literature}

This study contributes to the literature on the sources of persistent performance differences across firms: e.g., Bloom and Van Reenen (2007), Syverson (2011) and Gibbons and Henderson (2013). In contrast to studies such as Bloom and Van Reenen (2007) and Bloom, Sadun and Van Reenen (2013b), which characterize the overall quality of management practices, we focus on the interaction between management practices. In this context, we build on ideas from several fields. After the initial seminal work by Milgrom and Roberts (1990), the importance of complementarity in a firm's management practices and organizational activities was introduced to business practitioners by Porter (1996) and features prominently in the strategic management literature at least since Rivkin (2000); see also Porter and Siggelkow (2008) for a survey of this literature. Similar ideas regarding the importance of complementarity in production factors to explain persistent productivity differences have even been applied by Jones (2011) to total factor productivity (TFP) differences across countries. A major contribution to this literature is that our empirical results are representative of the entire population of business firms, irrespective of firm size and sector. In particular, our results are not restricted to the manufacturing sector. Moreover, since our estimates are based on what Athey and Stern (1998) describe as "reduced form tests of complementarity based on exclusion restrictions," they provide a valid characterization of management practice complementarity despite potential threats to identification outlined by Athey and Stern (1998).

Finally, we also contribute to the recent literature on endogenous firm productivity and organization, such as Grossman and Helpman (2002), Chassang (2010), Gibbons, Holden and Powell (2012), and Powell (2013). This literature is important in that it promises insight into the sources of firm productivity differences that is complementary to R\&D-based models, such as Klette and Kortum (2004), Luttmer (2007), and Acemoglu, Akcigit, Bloom, Kerr and Van Reenen (2013). However, empirical evidence on how management practices interact to influence firm productivity has been scant. Our goal is to encourage more theory development in this important field and to guide some of this new theory with our population-based estimates. 


\section{Theory}

To clarify the mechanisms through which decentralization of control and implementation of performance pay can either be substitutes or complements and to guide our empirical analysis in the rest of the paper, we develop a model of the trade-off between centralization and decentralization and how performance pay affects this trade-off. Like much of the recent empirical literature on management practices and decentralization, such as Bloom et al. (2012) and Bloom, Garicano, Sadun and Van Reenen (2013a), decentralization will be based on the logic developed by Garicano (2000) and Garicano and Rossi-Hansberg (2012). Specifically, more decentralization in these models allows a firm to economize on the business owner's time, thereby allowing her to focus only on complex and rare problems. On the other hand, decentralization involves effort costs to train employees and communication costs if employees encounter an unsolvable problem and need to explain it to the business owner. We extend this basic framework by assuming that part of the effort costs spent by employees to solve problems is unobservable. This gives rise to a classical moral hazard problem, such as Grossman and Hart (1983), which can potentially be addressed using performance pay.

There are two players in our model: a principal, $\mathrm{P}$, who can be considered the business owner, and an agent, A, who is an employee. Firms face a unit measure of problems $z \in[0,1]$ in their operations with cumulative distribution $F(z)$ and density $f(z)$. As is standard, we assume that these are ordered by frequency and complexity so that lower indices of $z$ denote simple and very frequent problems and high values of $z$ very complex and rare problems. This is formalized by assuming $f^{\prime}(z)<0$. Problems $z$ need to be solved to produce output; hence, every unsolved problem reduces output and therefore firm productivity.

To solve problems, both $\mathrm{P}$ and $\mathrm{A}$ have to exert effort to acquire knowledge to deal with the problems. This cost is higher the more complex the problem, and we denote the overall cost of solving problem $z$ by $a_{i} \cdot z$, where $i \in\{P, A\}$ and $a_{i}>0$. As in Bloom et al. (2013a), we assume that $\mathrm{P}$ knows all production tasks that employees A know, so that knowledge overlaps. If A cannot solve a particular problem, he will communicate the problem up the hierarchy to P. This entails a communication cost, which is denoted by $h$. To introduce a basic moral hazard problem into this framework, we assume that the agent's effort costs have two parts. First, $a_{1, A} \cdot z$ are costs associated with observable effort, as in Bloom et al. (2012). Second, there is a part of the effort costs denoted by $a_{2, A} \cdot z$ that is associated with unobservable effort. That is, A has a hidden effort choice $e \in\{0,1\}$ so that if he incurs effort $e=1$, he pays an additional cost $a_{2, A} \cdot z$. As usual, while the effort choice $e$ itself is hidden, the level of effort $\operatorname{costs} a_{2, A} \cdot z$ is common knowledge.

Production. Output is generated as a result of solving problems, where $z_{A}$ denotes 
the most complex problem that employees $\mathrm{A}$ are engaged in solving. If principal $\mathrm{P}$ is confronted with a problem, we assume she is able to solve it by incurring costs $a_{P}$. However, for employees, even for problems they in principle could solve, there is a random chance that the problem remains unsolved, possibly due to unforeseen issues. Let $x_{A}$ denote an indicator for whether the employee solved the problems he was confronted with. As is standard in principal-agent problems, we assume that the employee can increase output by exerting the hidden effort choice $e$. In other words, if the agent exerts effort, the fraction of problems that he can solve increases. Therefore, production is given by

$$
\begin{aligned}
1-F\left(z_{A}\right) & \text { for the principal and } \\
F\left(z_{A}\right) \cdot P\left(x_{A}=1 \mid e\right) & \text { for the agent. }
\end{aligned}
$$

Preferences. Business owner $\mathrm{P}$ is assumed to be risk neutral and the residual claimant of profit flows. Agent A is assumed to exhibit the following utility function

$$
U_{A}\left(w_{A}, z_{A}, e\right)=\ln \left(w_{A}\right)-a_{1, A} z_{A}-e \cdot a_{2, A} z_{A}
$$

where $w_{A}$ is her wage, which can be state-contingent. Since the effort associated with cost $a_{1, A} z_{A}$ is observable, we assume that this is directly paid for by the principal.

Timing. The general timing of our model can be described as follows. At $t=0$, $\mathrm{P}$ first decides on the degree of decentralization and then implements the optimal wage contract. That is, if performance pay is available, $\mathrm{P}$ will determine the optimal state-contingent wage payments; otherwise she will just set a constant wage to meet the agent's outside options. In $t=1$, the agent faces the organizational choices made by $\mathrm{P}$ and decides whether to exert effort. Production occurs and wage payments are made at the end of period 1 .

Performance Pay. We begin with the solution of the moral hazard problem. If performance pay is available, $\mathrm{P}$ chooses to condition wage payments on whether the agent solved a given problem. The optimal contract is designed to minimize expected wage payments subject to incentive-compatibility and participation constraints.

$$
\begin{aligned}
& \min _{w_{A}^{1}, w_{A}^{0}} P\left(x_{A}=1 \mid e=1\right) \cdot w_{A}^{H}+P\left(x_{A}=0 \mid e=1\right) \cdot w_{A}^{L} \\
& \quad \text { subject to: } \\
& \text { (IC) } E\left[U_{A}\left(w_{A}, z_{A}, e=1\right) \mid e=1\right] \geq E\left[U_{A}\left(w_{A}, z_{A}, e=0\right) \mid e=0\right] \text { and } \\
& \text { (IR) } E\left[U_{A}\left(w_{A}, z_{A}, e=1\right) \mid e=1\right] \geq U_{A}^{R} .
\end{aligned}
$$


To facilitate exposition, we assume that

$$
\begin{aligned}
& P\left(x_{A}=1 \mid e=0\right)=1-k \text { and } \\
& P\left(x_{A}=1 \mid e=1\right)=1-k+q,
\end{aligned}
$$

where $k$ is the probability that a random event renders the problem unsolvable and $q$ is the incremental gain in successful "problem solving" if the agent exerts effort, with $q<k$. Wages $w_{A}$ are contingent on problems being solved, so that $w_{A}=w_{A}^{1}$ if $x_{A}=1$ and $w_{A}=w_{A}^{0}$ if $x_{A}=0$.

By standard arguments, the solution to the contract design problem boils down to (IC) and (IR) holding exactly, pinning down contingent wages $\left(w_{A}^{1}, w_{A}^{0}\right)$. Given the functional form assumptions on utility and probabilities, performance pay is given by

$$
\begin{aligned}
& w_{A}^{1}\left(z_{A}\right)=\exp \left\{U_{A}^{R}+\frac{k}{q} \cdot a_{2, A} z_{A}\right\} \text { and } \\
& w_{A}^{0}\left(z_{A}\right)=\exp \left\{U_{A}^{R}-\frac{1-k}{q} \cdot a_{2, A} z_{A}\right\} .
\end{aligned}
$$

For notational convenience, let us define

$$
\bar{w}\left(z_{A}\right)=E\left[w_{A}\left(z_{A}\right) \mid e=1\right] .
$$

At this point, we highlight an important property of the optimal contract. In particular, the more complex the agent's tasks are - that is, the higher $z_{A}$-the higher the costs of incentive pay. In the appendix, we show that the following inequality holds:

$$
\bar{w}^{\prime}\left(z_{A}\right)>0 .
$$

The reason for this relationship is that for more complex problems the agent's effort costs are higher. Therefore, to induce A to incur this effort, the principal has to strengthen the high-powered incentives, which increases the costs of performance pay.

Decentralization without Performance Pay. The baseline case of our model without performance pay simplifies to the decentralization model of Bloom et al. (2012) and Bloom et al. (2013a), where one can replace the "trust" parameter in Bloom et al. (2012) with $P\left(x_{A}=1 \mid e=0\right)$. The degree of decentralization, $z_{A}$, is chosen to maximize profits:

$\Pi\left(z_{A}, 0\right)=\left[1-F\left(z_{A}\right)\right]+F\left(z_{A}\right) \cdot P\left(x_{A}=1 \mid e=0\right)-h \cdot a_{P} \cdot\left[1-F\left(z_{A}\right)\right]-a_{1, A} z_{A}-w_{A}^{R}$. 
The optimal degree of decentralization is implicitly determined by

$$
f\left(z_{A}^{*, 0}\right)=\frac{a_{1, A}}{h \cdot a_{P}-k},
$$

where $z_{A}^{*, 0}$ denotes the optimal degree of decentralization in a firm without performance pay. The comparative statics of this case follow from the fact that $f^{\prime}(z)<0$, as described in Bloom et al. (2012).

Decentralization with Performance Pay. The equilibrium choice of decentralization under the existence of performance pay maximizes

$\Pi\left(z_{A}, 1\right)=\left[1-F\left(z_{A}\right)\right]+F\left(z_{A}\right) \cdot P\left(x_{A}=1 \mid e=1\right)-h \cdot a_{P} \cdot\left[1-F\left(z_{A}\right)\right]-a_{1, A} z_{A}-\bar{w}\left(z_{A}\right)$.

In particular, the optimal degree of decentralization under performance pay $z_{A}^{*, 1}$ is given by

$$
f\left(z_{A}^{*, 1}\right)=\frac{a_{1, A}+\bar{w}^{\prime}\left(z_{A}\right)}{h \cdot a_{P}-k+q}
$$

Complementarity of Decentralization and Performance Pay. Whether decentralization and performance pay are complements or substitutes depends on the balance of two margins. First, performance pay can induce employees to make more efficient decisions by exerting more effort. This margin enters through the term $q=P\left(x_{A}=1 \mid e=1\right)-P\left(x_{A}=1 \mid e=0\right)$ and is a force toward decentralization. This is comparable to more "trust" in the framework of Bloom et al. (2012). The reason is that performance pay incentivizes exertion of unobservable effort, which in turn makes higher output more likely. Second, optimal performance pay will depend on the degree of decentralization, as shown in equation (2). More decentralizationthat is, higher $z_{A}$-will increase effort costs of agents, therefore requiring more high-powered incentives to induce effort. This is a force toward centralization, since decentralized decision-making becomes more costly. If the incremental gain from hidden effort of employees $q$ is relatively high, and the marginal performance pay costs of decentralization $\bar{w}^{\prime}\left(z_{A}\right)$ are low, then $z_{A}^{*, 1}>z_{A}^{*, 0}$ and decentralization and performance pay are complements. However, if marginal performance pay costs of decentralization $\bar{w}^{\prime}\left(z_{A}\right)$ are high and $q$ is low, decentralization and performance pay will be substitutes, or $z_{A}^{*, 1}<z_{A}^{*, 0}$. The following proposition summarizes the implications for our empirical section.

Proposition. In our baseline model of decentralization and performance pay, suppose there is exogenous variation in performance pay. Specifically, let $z_{A}^{*, 0}$ denote the optimal degree of decentralization without performance pay and $z_{A}^{*, 1}$ the optimal degree of decentralization with performance pay. Then, 


$$
z_{A}^{*, 1}>z_{A}^{*, 0} \text { if and only if } \frac{q}{h \cdot a_{P}-k}>\frac{\bar{w}^{\prime}\left(z_{A}^{*, 1}\right)}{a_{1, A}}
$$

In other words, in response to a change in performance pay induced by an exogenous change in the cost of providing high-powered incentives, decentralization of real decision authority increases if the incremental efficiency gain from effort outweighs the increased cost of performance pay. The comparative static in the proposition clarifies the potential mechanisms underlying our empirical approach. First, as suggested by the proposition, we will use exogenous variation in the adoption of performance pay to then trace out the optimal degree of decentralization. Second, we note that decentralization and performance pay can be either complements or substitutes in our model. That is, our model nests both possibilities so that, depending on our empirical results, the model could subsequently be calibrated to investigate the quantitative impact of the mechanisms we describe.

\section{Data and Measurement}

\subsection{Data}

To estimate the degree of complementarity between management practices, detailed data on the internal organization of firms and the implementation of management practices is necessary. The source of our data is the Workplace and Employee Survey (WES), conducted by Statistics Canada. It is based on a random stratified representative sample of establishments, with the universe of Canadian firms as the target population. The survey has a cross-sectional dimension of approximately 6,500 establishments over the time period 1999 to 2006, with a low overall attrition rate of around $20 \%$ cumulatively over the seven years. Of these 6,500 establishments, we focus on the sample of around 5,500 for-profit businesses. This data has several advantages over other existing micro-level data on management practices and internal firm organization. First, the WES has a comprehensive sectoral coverage, in contrast to either more narrow industry studies such as Ichniowski et al. (1997) or manufacturing-based studies such as Bloom et al. (2014). Second, since

the target population is the universe of Canadian business firms, the WES is not biased towards certain size classes as is the World Management Survey Data by Bloom and Van Reenen (2007). Third, another key advantage of the WES is that firm information is obtained within a culturally more homogeneous setting with commonly shared institutions relative to cross-country analysis based on the World 
Management Survey. ${ }^{4}$ This is important as it allows us to exclude many unobserved cultural factors that might bias our results.

\subsection{Measurement}

Decentralization of Real Decision Authority. The measurement of decentralization requires a credible approach to quantifying decision authority by organizational layer. To understand the potential measurement issues involved, take for example measures of formal decision authority based on occupational titles or organizational charts. As indicated by Aghion and Tirole (1997), managers higher up the hierarchy often only "rubberstamp" decisions actually made by non-managerial employees. Therefore, an increased range of formal responsibilities and reporting relations can imply either increased control or alternatively an even more limited attention to certain decisions and thus and thus a de facto reduction in control.

In contrast to such measures based on organizational charts, the WES includes detailed information regarding real decisions on 12 tasks across six layers in the organizational hierarchy. The survey questions are similar to the ones designed to measure worker autonomy, such as those used by Bresnahan, Brynjolfsson and Hitt (2002) or Bloom et al. (2013a), in that they allow us to measure the degree to which principals or agents are making decisions across 12 potential tasks. Specifically, the survey asks "Who normally makes decisions with respect to the following activities?" The respondent is then given a choice of 12 possible activities ranging from "daily planning of individual work" over "quality control" to "product and service development." There are six possible responses to the question of who makes decisions, which we call organizational layers: (i) non-managerial employees, (ii) work groups, (iii) work supervisors, (iv) senior managers, (v) individuals or groups outside the workplace (typically headquarters for multi-establishment firms), and (vi) business owners. $^{5}$

Table 1 summarizes the patterns of decision allocation across layers. For each of the 12 possible tasks, it shows the level of the hierarchy the task is typically decided and how many layers are involved. To calculate this, we assign non-managerial employees a value of 1 , work groups a value of 2 , etc. As the first two columns show, decisions on routine tasks like daily work planning are typically made in lower layers, such as by work supervisors, and hence are more decentralized. Complex tasks on the other hand, such as product or service development are decided at higher levels in the hierarchy, typically involving at least senior management. In particular, note that this pattern becomes stronger if we exclude firms that have

\footnotetext{
${ }^{4}$ The main exception to this relative homogeneity is the province of Quebec, a fact for which we explicitly control in our analysis.

5 Except for the summary statistics provided in table 1, we exclude the layer "work groups" from our analysis since it cannot be unambiguously assigned to either agents or principals.
} 
any involvement of business owners in decisions. The reason is that very small firms are naturally centralized, as business owners are typically involved in all activities in the firm, while larger firms take advantage of the division of labor in order to economize on the business owner's or senior manager's time. The last column shows that, on average, not much more than one layer is involved in decision-making for most activities, suggesting that the survey's layers are sufficiently disaggregated.

A particular advantage of the WES survey format is that it allows us to clearly separate principals from agents. Principals are defined as residual claimants of profit flows from the firm. In particular, since most firms are single-establishment entities, the separation between professional senior managers and business owners is important for identifying principals. Furthermore, for multi-unit firms, decisionmakers outside the establishment are typically headquarters, so that we identify the principal with the headquarters in such cases. On the other hand, agents are defined as any type of employees, including managers and non-managerial employees.

Since the data on the allocation of tasks to organizational layers is multi-dimensional, we use three functions that map to the real line, each providing different information about the decentralization of real decision authority. For the precise definition of our three measures of the degree of decentralization, let us begin by defining the following sets: $D^{\text {Principal }}$ is the set of activities or tasks that principals are involved in, $D^{\text {Manager }}$ the set of activities that management is involved in, $D^{\text {NonManager }}$ the set of tasks that non-managerial employees are involved in, and $D^{\text {Agent }}=D^{\text {Manager }} \cup D^{\text {NonManager }}$ the set of tasks that agents - that is, managerial or non-managerial employees - are involved in. Our three measures of the allocation of decision control within the firm are then defined as follows. ${ }^{6}$

$$
\begin{aligned}
\text { Control }_{i t}^{\text {Principal }} & =\sum_{d=1}^{12} 1\left\{d \in D_{i t}^{\text {Principal }} \backslash D_{i t}^{\text {Agent }}\right\} \\
& =\sum_{d=1}^{12} 1\left\{d \in D_{i t}^{\text {Principal }} \backslash\left(D_{i t}^{\text {Manager }} \cup D_{i t}^{\text {NonManager }}\right)\right\}, \\
\text { Control }_{i t}^{\text {Manager }} & =\sum_{d=1}^{12} 1\left\{d \in D_{i t}^{\text {Manager }} \backslash\left(D_{i t}^{\text {Principal }} \cup D_{i t}^{\text {NonManager }}\right)\right\}, \text { and } \\
\text { Control }_{i t}^{\text {NonManager }} & =\sum_{d=1}^{12} 1\left\{d \in D_{i t}^{\text {NonManager }} \backslash\left(D_{i t}^{\text {Principal }} \cup D_{i t}^{\text {Manager }}\right)\right\} .
\end{aligned}
$$

The indicator function $1\{d \in X\}$ equals one if condition $X$ is satisfied by $d$.

\footnotetext{
${ }^{6}$ We also analyzed the aggregate measure of tasks exclusively carried out by agents, $\sum_{d=1}^{12} 1\{d \in$ $\left.D_{i t}^{\text {Agent }} \backslash D_{i t}^{\text {Principal }}\right\}$. The results were similar to Control ${ }_{i t}^{\text {Principal }}$ with opposite sign-; hence we do not report it here separately. Moreover, since in the data the concept of the "agent" is much more ambiguous than that of the "principal," we focus on the two disaggregated agent measures of managers and non-managers.
} 
Control Principal $_{i t}$ counts the number of tasks that are exclusively carried out by the principal - i.e., business owner or headquarters - and is thus a measure of centralization of real decision authority. In contrast, the measures Control ${ }_{i t}^{\text {Manager }}$ and Control ${ }_{i t}^{\text {NonManager }}$ count the number of tasks exclusively allocated to agents, either managers (i.e., worker supervisors and senior management) or non-managers (i.e., non-managerial employees), respectively. Hence, the latter two variables measure the degree of decentralization of control. Note that the survey allows decision tasks to be decided by multiple layers within a firm. Since it is unclear how to allocate the actual control in such cases, our benchmark measures of decision and control are mutually exclusive. This implies, for example that a task is counted as being decided by the principal only if no other decision layer is involved in the decision. ${ }^{7}$

Performance Pay. The WES survey data offers a variety of information on performance-based compensation in firms. Specifically, it allows us to measure four different types of performance pay: (i) individual incentive pay, such as bonuses, commissions, piece-rates, etc.; (ii) group or team incentives, (iii) profit sharing agreements, and (iv) stock-based compensation. Additionally, the survey also asks about the presence of merit pay, which is defined as compensation for advanced education, such as a master's or a doctoral degree, and hence is non-performance-based pay. In principle, the data allows us to measure these types of performance by occupation, such as managers, production workers, sales representatives, administrators, technical support, etc. Since most firms adopt similar performance pay for all occupations, we start out using only the data on types of performance pay. To gauge how accurate the survey responses on performance pay are, we regress two quantitative compensation measures against the indicators of the presence of different types of performance pay. These two quantitative measures are average wages, defined as total payroll divided by the total number of employees, and average non-wage benefits, defined as non-payroll labor compensation per employee. As expected, table 2 shows that establishments with performance pay systematically pay higher average salaries, thereby lending support to the internal consistency of our data. To get a sense for the quantitative dimensions, consider two firms - one without and one with individual performance pay. The firm with individual performance pay will have annual salaries per employee that are on average $\$ 4.5$ higher than firms without performance pay. This might seem a small number at first, but note that performance pay is usually used for managers, professionals, and other nonproduction workers, who typically constitute a minority of the overall workforce in any establishment.

Standard principal-agent analysis characterizes very general forms of state-contingent compensation contracts to solve the moral hazard problem. Consequently, we mea-

\footnotetext{
${ }^{7}$ In unreported regressions, we obtain similar results with non-exclusive categorizations of decision control.
} 
sure the presence of performance pay with an indicator that is one if any form of performance pay is present. We exclude stock compensation from this measure, since information on stock compensation is completely missing for one year and only a very small fraction of firms offer stock compensation to their employees.

\section{Identification and Empirical Results}

\subsection{Instrumental Variables Strategy}

Endogeneity: The role of unobserved heterogeneity. Before describing our instrumental variables strategy, it is helpful to remember the possible biases when using simple ordinary least-squares (OLS) regressions. As was pointed out by Athey and Stern (1998), it is highly plausible that firms differ in their costs and benefits from adopting management practices. Examples of such heterogeneity include differences in skills of principals or differences in employee skills across firms. Depending on the source of such heterogeneity, a simple OLS regression of the adoption of decentralization on performance pay might be biased in different directions. On the one hand, if very skilled employees allow firms to decentralize more tasks and at the same time lower the costs of adopting performance pay, then OLS estimates of the complementarity of decentralization and performance pay would be upward biased. Firms would adopt these two management practices together not because they are complementary, but because the costs of adoption are positively correlated through unobserved employee skill. On the other hand, productivity differences across principals could bias OLS estimates of complementarity downward. Highly productive business owners or headquarters might be able to more effectively implement performance pay and at the same time might be more productive in making decisions, so more tasks would be centralized. In this case, firms with highly skilled principals might not decentralize decision-making while adopting performance pay. In other words, the benefits of decentralization and performance pay would be negatively correlated through unobserved principal skill, and hence estimates of complementarity using OLS would be downward biased.

Overview of $I V$. To identify the degree of complementarity between performance pay and decentralization, we exploit regional variation of income taxes across Canadian provinces as an instrument for the adoption of performance pay. The basic idea is that income tax distortions increase the cost of incentive provision through performance pay. To implement a given level of effort, a firm has to pay a higher marginal cost the higher income taxes are. This idea is succinctly summarized by Roberts (2004): "So, if income tax rates are lowered, it may be more attractive to increase the use of explicit performance pay, since the cost to the firm of providing intensity of incentives is reduced." This logic applies even more generally to 
income tax progression than to the level of income taxes; see Alford (2003). The reason is that, fundamentally, performance pay contracts are nonlinear in that they provide higher marginal reward in high-output states. A progressive income tax works exactly to offset this nonlinear incentive, since high incomes result in higher marginal tax rates; see Gentry and Hubbard (2004). Thus, regional variation in income tax progression can be compared to a "factor price variation" where the factor of production is the adoption of performance pay. Systematic variation in other management practices, such as decentralization in response to exogenous variation in tax progression, is comparable to a cross-price elasticity, in the spirit of Brynjolfsson and Milgrom (2013) and Aghion, Bloom and Van Reenen (2013). As emphasized by Aghion et al. (2013), for this identification strategy to be valid, our exclusion restriction is equivalent to the assumption that progressive income taxes do not directly impact decentralization decisions, except through the adoption of incentive pay. Under this exclusion restriction, we can utilize an IV strategy that provides a valid reduced form test of organizational complementarity, as argued by Arora (1996), Holmstrom and Milgrom (1994) and Athey and Stern (1998).

Income Tax Progression in Canada. Several features make Canada an ideal environment to apply the logic of our IV estimation. First, the levels of income taxation are generally far higher than, for example, in the US, thereby causing stronger distortions in the economy. Although the top statutory income tax rates at the federal level in Canada are in fact lower than the top federal income tax in the US, Murphy, Clemens and Veldhuis (2013) show that tax brackets are uniformly lower, so that top marginal taxes tend to apply even at relatively modest income levels. Second, and more importantly, regional variation in income taxes is more prevalent in Canada than in comparable federal countries. Murphy et al. (2013) state that "compared to citizens in other peer countries, Canadians tend to pay a lower share of their total income taxes to the federal government, and a greater share to provincial governments." Since Canadian provinces have full autonomy on both income tax rates and brackets, these provincial income taxes also tend to be applicable at relatively modest income levels.

Construction of the $I V$. Specifically, we use information on income tax progression in the panel of Canadian provinces going back to 1970. This data, from the annual publication Finances of the Nation, allows us to compute income taxes by province. Our measure of tax progression is residual income progression, a standard measure used in public finance to summarize tax progressivity; see Jakobsson (1976) and Musgrave and Musgrave (1989). It is defined as

$$
\rho=\frac{1-\mathrm{MTR}}{1-\mathrm{ATR}}
$$

where MTR is the top marginal income tax rate and ATR the average income tax rate. 
In this measure, $\rho=1$ corresponds to a flat tax system, while $\rho<1$ implies that the tax system exhibits progressivity. Consequently, higher values of $\rho$ imply less progressivity and will imply a higher incentive to adopt performance pay.

We adjust this basic measure of tax progression in two ways. First, the raw data on tax progression exhibits year-to-year fluctuations due to small random changes in statutory tax rates. Since we expect organizational changes, such as the implementation of performance pay, to exhibit long time lags, we smooth these annual fluctuations by taking 10-year averages of the tax progression measures. Second, for multi-province firms, we assign tax progression of the headquarters province as reference tax progression. We do this since the adoption of management practices in our data is mostly firm-wide. ${ }^{8}$ Firms that operate in multiple provinces have most of their establishments in the headquarters province, so it seems reasonable to assume that if firms adopt management practices, they use the same practices in other regions. ${ }^{9}$ Note that the bulk of firms are single-establishment firms and we will explicitly analyze multi-province firms in section 5 .

To summarize, the variation in our instrument is driven by provincial differences in tax progressivity and, to a limited degree, by within-province variation in tax progressivity. We extend our instrument to cross-industry variation later in the robustness section.

\subsection{Specification}

Here, we describe the precise econometric specification as a backdrop for the discussion of all our empirical results. As discussed earlier, the potentially endogenous variable of interest is the adoption of performance pay. We measure this management practice using an indicator denoted by $\mathrm{I}(\text { Performance Pay })_{i, t}$, for establishment $i$ at time $t$, which is one if there is any form of "pay for performance." We are interested in the interaction of performance pay with our three measures for decentralization. As noted by Athey and Stern (1998), the possibility of correlated unobserved adoption costs across firms renders raw correlations invalid for tests of complementarity. Hence, based on the idea that income tax progression is a valid instrument for the potentially endogenous variable I(Performance Pay $)_{i, t}$, the first

8 The fact that management practices in general and performance pay in particular do not vary much across region for multi-establishment, multi-regional firms suggests that other internal frictions, such as equity concerns and social norms, might prevent firms from writing optimal contracts given the local tax schedules.

${ }^{9}$ In unreported regressions, we also assigned tax progressions based on the actual establishment locations. When tax progression variables based on actual location and on headquarters location are included together to predict performance pay, only headquarters-based tax progression measures are highly significant, while tax progression based on actual location is insignificant. 
stage of the IV regression is

$$
\mathrm{I}(\text { Performance Pay })_{i, t}=\alpha_{\rho} \cdot \rho_{i, t}+\operatorname{controls}_{i, t}+\varepsilon_{1, i, t}
$$

where $\rho_{i, t}$ is the residual income progression measure described above. Since higher values of $\rho$ capture less progressive income taxes, one would expect that $\alpha_{\rho}>0$; thus, less progression makes implementation of performance pay more likely. If the exclusion restriction holds, then one can use this first stage to obtain the secondstage IV estimator

$$
\operatorname{Control}_{i, t}^{\text {Principal }}=\beta_{\mathrm{PP}} \cdot \mathrm{I}(\text { Performance Pay })_{i, t_{i, t}}+\operatorname{controls}_{i, t}+\varepsilon_{2, i, t}
$$

where $\beta_{\mathrm{PP}}$ is the causal effect of the adoption of performance pay on the degree of centralization of real decision authority. In particular, $\beta_{\mathrm{PP}}>0$ implies that adoption of performance pay increases decision control by the principal. In this case, decentralization and performance pay would be substitutes. On the other hand, $\beta_{\mathrm{PP}}<0$ implies that adoption of performance pay leads to less control by the principal and more delegation of decisions to employees, in which case decentralization and performance pay would be complements.

We use a number of standard variables to control for various obvious confounders. Among them are industry and year fixed effects to control for aggregate differences across industries or economy-wide shocks. Furthermore, we control for firm size as measured by the log of the total number of employees, the log of establishment age, and indicators for multi-establishment firms as well as exporter status. These are first-order controls, as one might expect that firms have a natural tendency to decentralize activities the larger they grow; simultaneously, the presence of more employees might make the implementation of performance pay more cost-effective, if the latter is associated with fixed costs of adoption.

We briefly note two properties of the estimator in use. First, to avoid running "forbidden regressions," we use a linear probability model for the first stage, as recommended by Angrist (2001) and Angrist and Pischke (2009). Second, we note that since our estimator is just-identified, any weak-instruments problem is likely to be diagnosed simply using correctly calculated second-stage standard errors; see Angrist and Pischke (2009). Table 3 provides first-stage estimates to ensure that the first stage is not insignificant, which is the only case for which the weak-instruments problems could matter in the just-identified case. ${ }^{10}$ These estimates show that in both probit and linear probability models, the first stage is highly significant and exhibits the expected sign for $\alpha_{\rho}$.

\footnotetext{
10 Note that it is difficult to interpret the magnitudes of the estimates given the nature of the dependent variable; hence we do not further discuss the results.
} 


\subsection{Results}

As argued in section 2, predictions based on a simple theory of decentralization with moral hazard are ambiguous on whether decentralization and performance pay are complements or substitutes. Our baseline results in table 4 suggest that they are complements. The first three columns provide simple OLS estimates of our measures of decision control and the adoption of performance pay. On average, adopting performance pay is associated with principals carrying out two tasks less and managerial agents carrying out one more, while non-managerial agents' control is not correlated with performance pay. The raw regression coefficients on performance pay are compatible with the presence of this complementarity, but as Athey and Stern (1998) indicate, they could also be generated by a positive correlation of adoption costs for both management practices. Columns 4 to 6 report IV estimates, which confirm the presence of complementarity performance pay and the decentralization of decisions from principals to agents. In response to exogenous adoptions of performance pay, firms reallocate real decision authority systematically away from principals and down the hierarchy. Note that the coefficient estimates for the IV estimates are mostly larger in absolute value than the OLS estimates, implying that the correlation of decentralization and performance pay in the OLS error term is negative. As discussed above, such a correlation is potentially indicative of the importance of omitting principal skill from the OLS regression. Another possibility that might generate this result is that performance pay is measured very noisily, so that our IV strategy reduces attenuation.

A notable feature of our empirical approach is our ability to separate agents into managerial employees, such as senior management and work supervisors, and nonmanagerial employees, such as production workers and sales representatives. This allows us to answer the question of how far down the hierarchy firms decentralize in response to the adoption of performance pay. It is evident in table 4 that firms tend to concentrate decision-making at the management level. That is, although they decentralize decision-making down from principals to agents in general, they also centralize decision-making away from non-managerial employees to managers. This is surprising for several reasons. First, one might have thought that since performance pay enables more efficient decision-making at all levels of the organization, the adoption of performance pay induces a general movement toward decentralization. This prediction would have implied that the performance pay coefficients for both, Control ${ }^{\text {Manager }}$ and Control ${ }^{\text {NonManager }}$ are positive. Second, there exist popular views that middle management is a wasteful bureaucratic layer. These views emphasize the importance of worker empowerment, so one would have expected that firms would reallocate tasks from the management to non-managerial employees. In that case, the coefficient on Control ${ }^{\text {Manager }}$ should have been negative, while the coefficient on Control ${ }^{\text {NonManager }}$ would have been positive. 
To support our basic findings on the concentration of decision control at the management level, we move beyond the analysis of decision control and analyze labor demand patterns in firms implementing performance pay. Panel A of table 5 shows the impact of an exogenous adoption of performance pay on the occupational composition of firms. In particular, our dependent variable is the proportion of the workforce at an establishment, that comprises of one of five occupational classes: (i) managers, (ii) production workers, (iii) professionals, (iv) sales representatives, and (v) administrative staff. The key result is that establishments implementing performance pay employ more managers as a proportion of their workforce. So not only do firms that adopt performance pay driven by exogenous reasons allocate more decision responsibility to management, they also maintain larger pools of managers to meet these responsibilities.

One question is whether firms that implement performance pay do not actually employ more managers, but might tend to lay-off non-managers, so that the fraction of non-managers in the workforce is higher. A simple mechanism through which this could occur is one in which managers begin cutting costs by laying off non-managerial employees. This might explain why non-managerial employees are given less control over decisions - there might simply be less of them at the firm. However, panel B of table 5 shows that the coefficients on hiring and firing have the wrong sign with firms implementing incentive pay laying off less, although the estimates are not statistically significant and implausibly large. Hiring rates at these establishments are lower, but the effect is not statistically significant. Instead, panel $\mathrm{C}$ of table 5 suggests that firms that adopt performance pay shift their hiring towards managers. This evidence is compatible with a view that the largest gains from implementation of performance pay occur through more efficient decision-making of managers. Consequently, firms tend to not only concentrate control at the management level, but also tend to hire more managers to deal with the increased responsibilities. Overall, the data are compatible with the view that management plays a key role at the intersection of production and non-production decisions. Our findings are also supportive of the hypothesis advanced by Atalay et al. (2013) that the nature of firms is intimately connected to their role in "mediating managerial supervision and control."

\subsection{Extension: Organizational Change}

So far we have documented how firms that adopt performance pay for exogenous reasons, concentrate control at the management level and hire more professional managers. However, what do these managers do with their wider range of responsibilities? This section attempts to provide some answers to this question. While we find this question intriguing, we have to caution the reader that the wider application of our IV to variables other than decision control potentially threatens 
identification. Depending on the dependent variable, tax progressivity might have a direct impact on organizational changes beyond its influence through performance pay. However, the plausibility of such a direct mechanism must be decided on a case-by-case basis.

Panel D of table 5 summarizes the IV results for six management practices: (i) decrease in the degree of centralization, (ii) re-engineering of business processes, (iii) downsizing, (iv) adoption of TQM, (v) outsourcing, and (vi) delayering of managerial hierarchies. In each of these cases, the dependent variable is a survey response to the question: "Has your workplace experienced any of the following forms of organizational change... (in the past year)?" An affirmative answer is coded as one, while a negative answer is coded as zero. The first notable result that provides another validity check on our results is that establishments that implement performance pay do not seem to systematically decrease the degree of centralization. This seems puzzling in light of the clear movement of the delegation of decision-making from principals to agents in general. However, it is in fact completely consistent once we take into account the simultaneous centralization of decisions from non-managerial employees to management. This shows that it might be difficult for survey respondents to answer this survey question unambiguously, because as our previous results show, there are competing forces at work; decentralization from principals to managers, but also centralization from non-managers to managers. Moreover, this variable probably has substantial measurement error, much more so than the allocation of tasks to decision layers.

One of the management practices more frequently used by managers when adequately incentivized with performance pay is business process re-engineering (or "re-engineering"). We note that this question in the survey provides a brief description of this management practice as "redesigning processes to improve performance and cost." After being popularized in the U.S. by Hammer (1990), business process re-engineering has often been criticized as a cover for downsizing instead of a valid approach to improve firm performance. While a comprehensive evaluation of reengineering is beyond the scope of our study, our data does allow us to investigate whether managers implementing re-engineering downsize their workforce simultaneously. In particular, the survey defines downsizing as "reducing the number of employees on payroll to reduce expenses: it is part of a reorganization in the workplace and not simply a response to a drop in demand." The fourth column in panel $\mathrm{D}$ of table 5 shows that although firms implementing performance pay are more likely to adopt re-engineering, they are not much more likely to downsize. The latter result is consistent with our earlier findings regarding the overall layoff and quit rate at firms. To summarize, performance pay seems to induce managers to seek more efficient business processes, but does not necessarily lead them to downsize the workforce.

It is also worth highlighting that exogenous implementation of performance pay 
leads to more likely adoption of TQM. This is surprising, since a widespread assumption regarding the effective implementation of this management practice is that it is complementary to worker empowerment or more decentralization towards non-managerial employees. In contrast, our empirical results suggest that worker empowerment and TQM are not necessarily complements, but are potentially substitutes.

Up to this point, much of our discussion of the knock-on effects of implementation of performance pay on other management practices has focused on inferring information regarding which decisions managers might make. But are there possible implications of the implementation of performance pay for the number of managerial hierarchies themselves? A natural starting point for this question might be a version of Garicano (2000), in which the number of hierarchies is endogenously determined, in contrast to our baseline model that keeps the number of hierarchical levels fixed. According to Garicano (2000), an organization will be able to deal with more problems and responsibilities if the number of layers is high. Therefore, one might conjecture that an increased concentration of decisions at the management level might also increase the number of managerial layers. To analyze this point, we use the reduction in the number of managerial levels (delayering) as a dependent variable in the last column of panel $\mathrm{D}$ of table 5 . It shows that the simple intuition from a model of endogenous hierarchies is not borne out in the data. Hence, although management exhibits greater control over decisions in the firm once performance pay is implemented, it does not deal with these responsibilities by adding more real decision layers in the organization. On the contrary, there is a systematic tendency to delayer in these firms.

\section{Robustness}

In this robustness section, we address two potential concerns. First, given that most of the exogenous variation in our instrument is driven by regional differences, it is possible that unobserved omitted variables at the local level render our identification invalid. Second, there are possible alternative explanations for the specific decentralization patterns observed in the data, either in addition to our proposed mechanism via performance pay or in lieu of it.

\subsection{Within-Province Variation}

To explore whether unobserved regional factors drive our results, we focus on the sample of firms that operate across multiple provinces. For these firms, we include a full set of province fixed effects that controls for unobserved factors in their location. At the same time, since their assigned tax progression measures are based 
on the headquarters region, the instrument is still valid. In other words, we compare establishments which are part of multi-province firms within the same location and predict that establishments with headquarters located in regions with high tax progressivity are less likely to adopt performance pay than establishments in the same location that have headquarters in regions with low tax progressivity. This alternative IV strategy takes full account of unobserved confounders in an establishment's location without compromising our identification strategy. The IV estimates in columns 1 to 3 of table 6 are quantitatively similar to our benchmark estimates, although less precisely estimated due to the loss of $90 \%$ of the observations. The coefficient on both those decision tasks controlled by the principal and those tasks controlled by non-managerial employees stays significant. Note also that the coefficient on the manager tasks stay significant at the $10 \%$ level, although we cut our sample in this robustness check by $90 \%$.

\subsection{Industry-Province Interaction IV}

Another way to address possible concerns about using only regional variation in our IV strategy is to exploit more industry level variation. To this end, we use 4digit industry variation in the share of firms reporting product innovations in 1999. As in Holmstrom (1989), the idea is that employee activities that are important for innovation are hard to monitor. As a result, firms that operate in industries where innovation is important are more likely to adopt performance pay if tax progression is low. Following this idea, we use regional tax progression as well as the interaction of regional tax progressivity with the share of innovating firms as our instruments. Since the IV variation is now also based on 4-digit industry variation, we cluster our standard errors by year, region, and industry. The Craig-Donald F-statistic to test for weak IVs has a value of 32.75 , and the first stage is again highly statistically significant. Columns 4 to 6 of table 6 show estimates of the effect of performance pay adoption on decentralization that are very similar to the simple IV estimates in table 4. However, the standard errors do increase somewhat, indicating that the industry variation does add some noise.

\subsection{Alternative Explanations}

We argued that using provincial differences in income tax progression can be used to instrument for the adoption of performance pay, even in the presence of unobserved heterogeneity in adoption cost, as emphasized by Athey and Stern (1998). If our identification strategy is valid, the IV estimator recovers a valid estimate of the degree of complementarity between performance pay and decentralization. Here, we explore a number of alternative explanations for our results and argue that our basic findings are robust in controlling for those extensions. 
- Industry trends in technology or competition. Potential unobserved factors influencing performance pay and decentralization include industry trends in technology and competition. For example, suppose firms adopt better computer technology that allows them to decentralize tasks more easily. At the same time, this technology might provide an independent noisy signal on the effort of employees, effectively lowering the cost of performance pay. Consequently, firms might implement decentralization and performance pay, driven by industry trends in technology. An alternative plausible industry trend is the intensification of competition. On one hand, this could lead to decentralization of decision-making, as argued by Bloom, Sadun and Van Reenen (2010). On the other hand, competition might induce principals to adopt performance pay, as in the model of Raith (2003). To control for these types of mechanisms, we include a full set of industry-time interactions to capture unobserved industry trends in competition and technology. In case competition is not only national but has an important regional component, we also use survey response data on perceived local competition. More specifically, the WES asks respondents to indicate whether they think that local competition is important. We therefore include an indicator which is one if the firm perceived local competition to be relevant.

- Total number of tasks and organizational layers. Firms might also differ in the complexity of the problems they typically have to solve. For example, some firms with simple business processes might not have to formally allocate certain decisions, such as customer service, to the business owner or employees. Other firms with complicated just-in-time production will need to assign a large number of tasks to decision-makers, and decentralization might thus be natural. Furthermore, such firms will also tend to implement performance pay because of moral hazard problems in these complex business processes. We use two proxies to control for this issue. The first is a direct measure of the overall number of tasks the firm is involved in. The second is a proxy for the number of decision layers the firm has, which we call "task scope." We base this measure on ideas of Garicano (2000) that organizations with more layers economize on managers' time and therefore are able to solve more complex problems. We construct this measure in the following manner: for each possible decision layer, we check whether the firm has assigned any of the 12 decision tasks to this layer. If it has done so, we infer that this layer exists; otherwise, we presume that the firm does not use this layer in decision-making problems, and hence we ignore it.

- Unobserved employee skill. Employee skill can lower costs of both decentralization and performance pay. Highly skilled employees might be more likely to require little training to make decisions on relatively complicated tasks. Fur- 
thermore, performance pay might then just be present to provide high wage payments to very skilled employees to induce a sorting toward high-skill employees, as shown by Lazear (2000). To control for this explanation, we include the average wage - i.e., the ratio of payroll to number of total workers - as well as the fraction of workers in the top earnings bracket, which we call "fraction of top earners," to proxy for the presence of highly skilled workers.

- Novelty business strategy. The joint adoption of performance pay and decentralization might also result from a firm's business strategy that is based on innovating and introducing new products. For example, a firm trying to innovate might decentralize decision-making to benefit from information acquisition of employees, as in Aghion and Tirole (1997). At the same time, the firm might want to implement performance pay to give employees incentives to participate in innovation. To control for this mechanism, we include an indicator that takes the value of one if a firm's top priority in its business strategy is innovation. This measure is more fully developed and explained in Yang, Kueng and Hong (2014).

- Risk. In response to empirical studies suggesting a positive correlation between risk and performance pay, theoretical models such as Prendergast (2002) have argued that risk can drive both decentralization and performance pay. Therefore, risk could be a potential confounder biasing our results towards a finding of complementarity between performance pay and decentralization. We include the standard deviation of operating margin at the establishment level as an explicit measure of risk.

- French culture. For most of our sample, it is safe to assume that the cultural differences across Canadian provinces are minor. The obvious exception is Quebec. There are several ways in which the presence of French culture in Canada could influence our results. First, regarding decentralization, Bloom et al. (2012) note that there is a tendency to centralize decision-making in the French culture. Second, French culture as part of continental European culture has been argued to exhibit a larger degree of inequity aversion based on different equilibrium beliefs regarding luck vs. meritocracy; see, e.g., Alesina and Angeletos (2005). This inequity aversion might prevent firms under French influence from implementing performance pay. We directly control for the effects of French culture by including an indicator of whether the establishment is located in Quebec.

Tables 7-9 display the results from the robustness checks of our results. The specifications include all the standard controls we used in previous specifications. These controls are omitted here due to space constraints. As these tables show, all 
baseline results are robust, whether the control variables are included sequentially or altogether. In particular, the size of the relationship is quantitatively similar across all specifications and remains highly statistically significant.

While the additional control variables do not affect our estimates of the degree of complementarity between performance pay and decentralization, one might ask whether the effects on our control variables are consistent with the mechanisms we described above. This is indeed the case with most mechanisms, even as the signs on some coefficients are not conclusive in this respect. For example, firms with more decision layers tend to be more decentralized as principals are making decisions on a lower number of tasks. This is compatible with the notion of Garicano (2000) that more specialization is related to a higher number of layers. Similarly, higher average salaries are correlated with a lower degree of decision authority at the level of the principal and more decision authority by non-managerial employees. This is exactly the type of systematic pattern one would expect if higher salaries capture more skilled workers. However, note that in this context, the fraction of top earners in firms enters with the opposite sign, suggesting that firms with more top earners have a more centralized decision-making process.

Finally, a number of results in these robustness regressions are inconsistent with the type of mechanism they are constructed to control for. The most prominent example is the correlation of risk and decentralization. In theoretical models such as Prendergast (2002), firms that are exposed to more risk tend to decentralize decision-making and adopt performance pay. In contrast, as table 7 shows, risk is positively but insignificantly correlated with centralization of decision-making. One reason for this puzzling result could be the fact that the model of Prendergast (2002) is a better description of the the delegation of decisions between managers and non-managers instead of principals and agents. In other words, even if principals do not delegate any tasks to employees, it might still be possible that managers delegate tasks to non-managerial employees. But as tables 8 and 9 indicate, firms that are exposed to more risk tend to grant managers more decision authority than non-managerial employees.

\section{Conclusion}

Our study provides the first causal economy-wide evidence on management practice complementarity, combining regional variation on income tax progression with business-level data on internal organization from Canada. By estimating the average degree of complementarity between decentralization and performance pay, our results provide a benchmark to calibrate quantitative models of endogenous productivity and management practices, such as agent-based models used by Rivkin (2000). We also provide evidence clarifying the mechanism through which management prac- 
tices may influence productivity outcomes, complementing previous work highlighting their importance in explaining productivity differences across firms (Bloom and Van Reenen (2007)). Management practices may be valuable in isolation for productivity, but different practices may also complement each other, making joint adoption of certain types of management practices more valuable.

We note that our findings suggest several avenues for future work. While we provide evidence of complementarity of decentralization and incentive pay, estimating the actual effects on firm productivity of joint adoption are a logical extension of our findings. As argued by Athey and Stern (1998), management practice complementarity should have important consequences for productivity estimation, where complementary management practices must be evaluated together to recover valid estimates of the productivity gains from adopting management practices. One potential path for future work in this area would be to combine an instrumental variables approach with the structural estimator proposed by Athey and Stern (1998) and Kretschmer et al. (2012). Also, our results suggest that the deployment of professional management is a key function of firms, complementing the findings of Atalay et al. (2013). However, the precise causal mechanisms linking the presence of professional management, the importance of management practices, and firm productivity outcomes is not yet well understood. Future empirical work investigating these causal relationships would add valuable insight into how management practices are implemented within firms, and provide greater clarity into the link between internal organizational factors and productivity outcomes. Finally, future work could also consider the link between management practice complementarity and financial frictions. In a model of firm dynamics that includes both factors, management practice complementarity is likely to strongly interact with credit frictions, where credit constraints may have a significant impact on firm productivity differences and aggregate productivity. Taken together, these possible avenues for future work suggest that complementarity of management practices offers one possible explanation for why productivity differences remain so significant and persistent across firms.

\section{References}

Acemoglu, D., U. Akcigit, N. Bloom, W. Kerr, and J. Van Reenen, "Innovation, reallocation and growth," mimeo, Stanford University, 2013.

Aghion, P. and J. Tirole, "Formal and real authority in organizations," Journal of Political Economy, 1997.

_, N. Bloom, and J. Van Reenen, "Incomplete contracts and the internal organization of firms," Journal of Law, Economics and Organization, 2013.

Alesina, A. and M. Angeletos, "Fairness and Redistribution: US vs. Europe," American Economic Review, 2005. 
Alford, S., "The effect of personal income tax on corporate agency costs," mimeo, Asper School of Business, University of Manitoba, 2003.

Angrist, J., "Models with dummy endogenous regressors: simple strategies for empirical practice," Journal of Business and Economic Statistics, 2001.

_ and S. Pischke, Mostly harmless econometrics, Prince, 2009.

Arora, A., "Testing for complementarities in reduced form regressions: a note," Economics, 1996.

Atalay, E., A. Hortascu, and C. Syverson, "Vertical integration and input flows," American Economic Review, 2013.

Athey, S. and S. Stern, "An empirical framework for testing ttheorie about complementarity in ororganization design," NBER Working Paper, 1998.

Baily, M., C. Hulten, and D. Campbell, "Productivity Dynamics in Manufacturing Plants," Brookings Papers on Economic Activity: Microeconomics, 1992.

Bester, H. and D. Kremer, "Delegation and Incentives," Rand Journal of Economics, 2008.

Bloom, N. and J. Van Reenen, "Measuring and Explaining Management Practices Across Firms and Countries," Quarterly Jounral of Economics, 2007.

_ , L. Garicano, R. Sadun, and J. Van Reenen, "The distinct effects of information technology and communication technology on firm organization," Management Science, 2013.

_ , R. Sadun, and J. Van Reenen, "Does product market competition lead firms to decentralize?," American Economic Review Papers and Proceedings, 2010.

_ , _ , and _ , "The organization of firms across countries," Quarterly Jounral of Economics, 2012.

_ , _, and _ , "Management as Technology?," mimeo, Stanford University, 2013.

Bloom, Nicholas, Erik Brynjolfsson, Lucia Foster, Ron S Jarmin, Megha Patnaik, Itay Saporta Eksten, and John Van Reenen, "IT and Management in America," 2014.

Bresnahan, T., E. Brynjolfsson, and L. Hitt, "Information technology, workplace organization and the demand for skilled labor: firm-level evidence," Quarterly Jounral of Economics, 2002.

Brynjolfsson, E. and P. R. Milgrom, "Complementarity in Organizations," Handbook of Organizational Economics, 2013.

Chassang, S., "Building Routines: Learning, Cooperation and the Dynamics of Incomplete Relational Contracts," American Economic Review, 2010.

Drucker, P., The Concept of the Corporation, Transaction Publishers, 1949.

Garicano, L., "Hierachies and the organization of knowledge in production," Journal 
of Political Economy, 2000.

_ and E. Rossi-Hansberg, "Organizing Growth," Journal of Economic Theory, 2012.

Gentry, W. and G. Hubbard, "The Effects of Progressive Income Taxation on Job Turnover," Journal of Public Economics, 2004.

Gibbons, R. and R. Henderson, "What do managers do?," Handbook of Organizational Economics, 2013.

_, R. Holden, and M. Powell, "Organization and information: firms' governance choices in rational-expectations equilibrium," Quarterly Journal of Economics, 2012 .

Grossman, G. and E. Helpman, "Integration vs. outsourcing in industry equilibrium," Quarterly Journal of Economics, 2002.

_ and O. Hart, "An Analysis of the principal-agent problem," Econometrica, 1983.

Hammer, M., "Reengineering work: don't automate, obliterate!," Harvard Business Review, 1990.

Holmstrom, B. and P. Milgrom, "Multitask Principal-Agent Analyses: Incentive Contracts, Asset Ownership and Job Design," Jounral of Law, Economics and Organization, 1991.

_ and _, "The firm as an incentive system," American Economic Review, 1994.

Holmstrom, Bengt, "Agency Costs and Innovation," Journal of Economic Behavior and Organization, 1989.

Ichniowski, C., K. Shaw, and G. Prennushi, "The effects of human resource management practices on productivity: a study of steel finishing lines," American Economic Review, 1997.

Jakobsson, U., "On the measurement of the degree of progression," Journal of Public Economics, 1976.

Jensen, M.C. and W.H. Meckling, "Theory of the Firm: Managerial Behavior, Agency Costs, and Ownership Structures," Journal of Financial Economics, 1976, 3 (4), 305-360.

Jones, Charles I., "Intermediate Goods and Weak Links in the Theory of Economic Development," American Economic Journal: Macro, 2011.

Klette, T. and S. Kortum, "Innovating firms and aggregate innovation," Journal of Political Economy, 2004.

Kretschmer, T., E. Miravete, and J. Pernias, "Competitive pressure and the adoption of complementary innovations," American Economic Review, 2012.

Krishna, V. and J. Morgan, "Contracting for information under imperfect committment," Rand Journal of Economics, 2008. 
Laffont, J. and D. Martimort, The theory of incentives: the principal-agent model, Princeton University Press, 2002.

Lazear, E., "Performance Pay and Productivity," American Economic Review, 2000.

Luttmer, E., "Selection, growth and the size distribution of firms," Quarterly Journal of Economics, 2007.

Milgrom, P. and J. Roberts, "The economics of modern manufacturing: technology, strategy and organization," American Economic Review, 1990.

Milgrom, Paul and John Roberts, "Complementarities and fit strategy, structure, and organizational change in manufacturing," Journal of Accounting and Economics, 1995.

Murphy, R., J. Clemens, and N. Veldhuis, "The economic costs of increased marginal tax rates in Canada," Studies in Budget and Tax Policy, Frazier Institute, 2013.

Musgrave, R. and P. Musgrave, Public finance in theory and practice, McGraw-Hill, 1989.

Penrose, E., The theory of the growth of the firm, Oxford University Press, 1959.

Porter, M., "What is strategy?," Harvard Business Review, 1996.

_ and N. Siggelkow, "Contextuality within activity systems and substainability of competitive advantage," Academy of Management Perspectives, 2008.

Powell, M., "Productivity and credibility in industry equilibrium," mimeo, Kellogg School of Management, Northwestern University, 2013.

Prendergast, C., "The tenuous trade-off between risk and incentives," Journal of Political Economy, 2002.

Raith, M., "Competition, risk and managerial incentives," American Economic Review, 2003.

Rivkin, J., "Imitation of complex strategies," Management Science, 2000.

Roberts, J., The Modern Firm, Oxford, 2004.

Steen, E. Van Den, "Disagreement and the Allocation of Control," Journal of Law, Economics and Organization, 2010.

Syverson, C., "What determines productivity?," Journal of Economic Literature, 2011.

Yang, Mu-Jeung, Lorenz Kueng, and Bryan Hong, "Business Strategy and the Management of Firms," mimeo, University of Washington, 2014. 
Table 1: Summary statistics of the hierarchical layers

\begin{tabular}{|c|c|c|c|}
\hline & \multicolumn{2}{|c|}{ Average layer } & \multirow[b]{2}{*}{ No. of layers } \\
\hline & layers & $\begin{array}{l}\text { excl. } \\
\text { bus. Own. }\end{array}$ & \\
\hline \multicolumn{4}{|l|}{ Tasks/Activities: } \\
\hline 1. Daily work planning & $\begin{array}{c}3.24 \\
{[0.032]}\end{array}$ & $\begin{array}{c}2.85 \\
{[0.08]}\end{array}$ & $\begin{array}{c}1.16 \\
{[0.012]}\end{array}$ \\
\hline 2. Weekly work planning & $\begin{array}{c}3.32 \\
{[0.031]}\end{array}$ & $\begin{array}{c}2.97 \\
{[0.08]}\end{array}$ & $\begin{array}{c}1.17 \\
{[0.012]}\end{array}$ \\
\hline 3. Purchase of supplies & $\begin{array}{c}3.34 \\
{[0.031]}\end{array}$ & $\begin{array}{c}3.09 \\
{[0.076]}\end{array}$ & $\begin{array}{c}1.17 \\
{[0.012]}\end{array}$ \\
\hline 4. Equipment maintenance & $\begin{array}{c}3.4 \\
{[0.035]}\end{array}$ & $\begin{array}{c}3.13 \\
{[0.088]}\end{array}$ & $\begin{array}{c}1.17 \\
{[0.014]}\end{array}$ \\
\hline 5. Customer relations & $\begin{array}{c}3.47 \\
{[0.028]}\end{array}$ & $\begin{array}{c}3.2 \\
{[0.076]}\end{array}$ & $\begin{array}{c}1.25 \\
{[0.017]}\end{array}$ \\
\hline 6. Quality control & $\begin{array}{c}3.55 \\
{[0.025]}\end{array}$ & $\begin{array}{c}3.37 \\
{[0.075]}\end{array}$ & $\begin{array}{c}1.25 \\
{[0.017]}\end{array}$ \\
\hline 7. Follow-up of results & $\begin{array}{c}3.56 \\
{[0.026]}\end{array}$ & $\begin{array}{c}3.25 \\
{[0.075]}\end{array}$ & $\begin{array}{c}1.17 \\
{[0.012]}\end{array}$ \\
\hline 8. Training & $\begin{array}{c}3.63 \\
{[0.025]}\end{array}$ & $\begin{array}{c}3.5 \\
{[0.062]}\end{array}$ & $\begin{array}{c}1.17 \\
{[0.011]}\end{array}$ \\
\hline 9. Filling vacancies & $\begin{array}{c}3.84 \\
{[0.018]}\end{array}$ & $\begin{array}{c}3.65 \\
{[0.059]}\end{array}$ & $\begin{array}{c}1.08 \\
{[0.0082]}\end{array}$ \\
\hline 10. Product or service development & $\begin{array}{c}3.85 \\
{[0.02]}\end{array}$ & $\begin{array}{c}3.8 \\
{[0.064]}\end{array}$ & $\begin{array}{c}1.12 \\
{[0.011]}\end{array}$ \\
\hline 11. Production technology choice & $\begin{array}{c}3.86 \\
{[0.02]}\end{array}$ & $\begin{array}{c}3.84 \\
{[0.066]}\end{array}$ & $\begin{array}{c}1.09 \\
{[0.0089]}\end{array}$ \\
\hline 12. Set staffing levels & $\begin{array}{c}3.87 \\
{[0.017]}\end{array}$ & $\begin{array}{c}3.71 \\
{[0.059]}\end{array}$ & $\begin{array}{c}1.07 \\
{[0.007]}\end{array}$ \\
\hline Number of obs. & 5,311 & 2,246 & 5,311 \\
\hline
\end{tabular}

Notes: Organizational layers are coded as 1 (non-managerial employees), 2 (work group), 3 (work supervisor), 4 (senior manager), 5 (headquarters), 6 (business owner). All data is for the 2003 cross section. The first column displays population-weighted average layers involved across the 12 tasks. The second column displays the population-weighted average number of layers involved across the 12 tasks where the business owner is not involved at all in decision-making. The third column displays the average number of layers involved in a given task across all firms. All summary statistics are weighted using survey weights to make results representative for all business firms in Canada. Standard errors in parenthesis. 
Table 2: Performance pay and average compensation

\begin{tabular}{|c|c|c|}
\hline Dependent variables: & $\begin{array}{l}\text { Avg. annual } \\
\text { salary }\end{array}$ & $\begin{array}{c}\text { Avg. non-wage } \\
\text { benefits }\end{array}$ \\
\hline \multicolumn{3}{|l|}{ Performance Pay Adoption: } \\
\hline I(Individual Incentives) & $\begin{array}{c}4.479^{* * *} \\
(0.887)\end{array}$ & $\begin{array}{c}0.131 \\
(0.139)\end{array}$ \\
\hline I(Group Incentives) & $\begin{array}{l}2.205^{*} \\
(1.163)\end{array}$ & $\begin{array}{c}0.262 \\
(0.179)\end{array}$ \\
\hline I(Profit Sharing) & $\begin{array}{l}3.364^{* *} \\
(1.320)\end{array}$ & $\begin{array}{c}0.171 \\
(0.162)\end{array}$ \\
\hline I(Stock Compensation) & $\begin{array}{l}4.182^{*} \\
(2.385)\end{array}$ & $\begin{array}{l}0.852^{*} \\
(0.454)\end{array}$ \\
\hline \multicolumn{3}{|l|}{ Non-Performance Pay Adoption: } \\
\hline I(Merit-Based Pay) & $\begin{array}{c}0.493 \\
(1.267)\end{array}$ & $\begin{array}{c}0.138 \\
(0.252)\end{array}$ \\
\hline \multicolumn{3}{|l|}{ Firm Characteristics: } \\
\hline $\log ($ employment $)$ & $\begin{array}{c}0.934^{* *} \\
(0.409)\end{array}$ & $\begin{array}{l}-0.121 \\
(0.103)\end{array}$ \\
\hline $\log ($ establishment age) & $\begin{array}{c}1.382^{* * *} \\
(0.375)\end{array}$ & $\begin{array}{c}0.469^{* * *} \\
(0.084)\end{array}$ \\
\hline I(multi-establishment firm) & $\begin{array}{c}1.695 \\
(1.702)\end{array}$ & $\begin{array}{l}1.079^{* *} \\
(0.425)\end{array}$ \\
\hline I(exporter) & $\begin{array}{c}2.374^{* *} \\
(0.981)\end{array}$ & $\begin{array}{c}0.093 \\
(0.151)\end{array}$ \\
\hline Industry FE & Yes & Yes \\
\hline Time FE & Yes & Yes \\
\hline Number of obs. & 17,104 & 12,568 \\
\hline R-squared & 0.299 & 0.254 \\
\hline
\end{tabular}

Notes: Dependent variables are: payroll/(total employees) in column 1 and (nonpayroll labor compensation)/(total employees) in column 2. Industry fixed effects are at the 4-digit NAICS level. Data is for years 2001, 2003, and 2005, excluding 1999, which does not include data on stock compensation. Standard errors are clustered by sampling strata, which are broad industry-size-region categories. All regressions use sampling weights. 
Table 3: First stage - performance pay adoption on tax progression

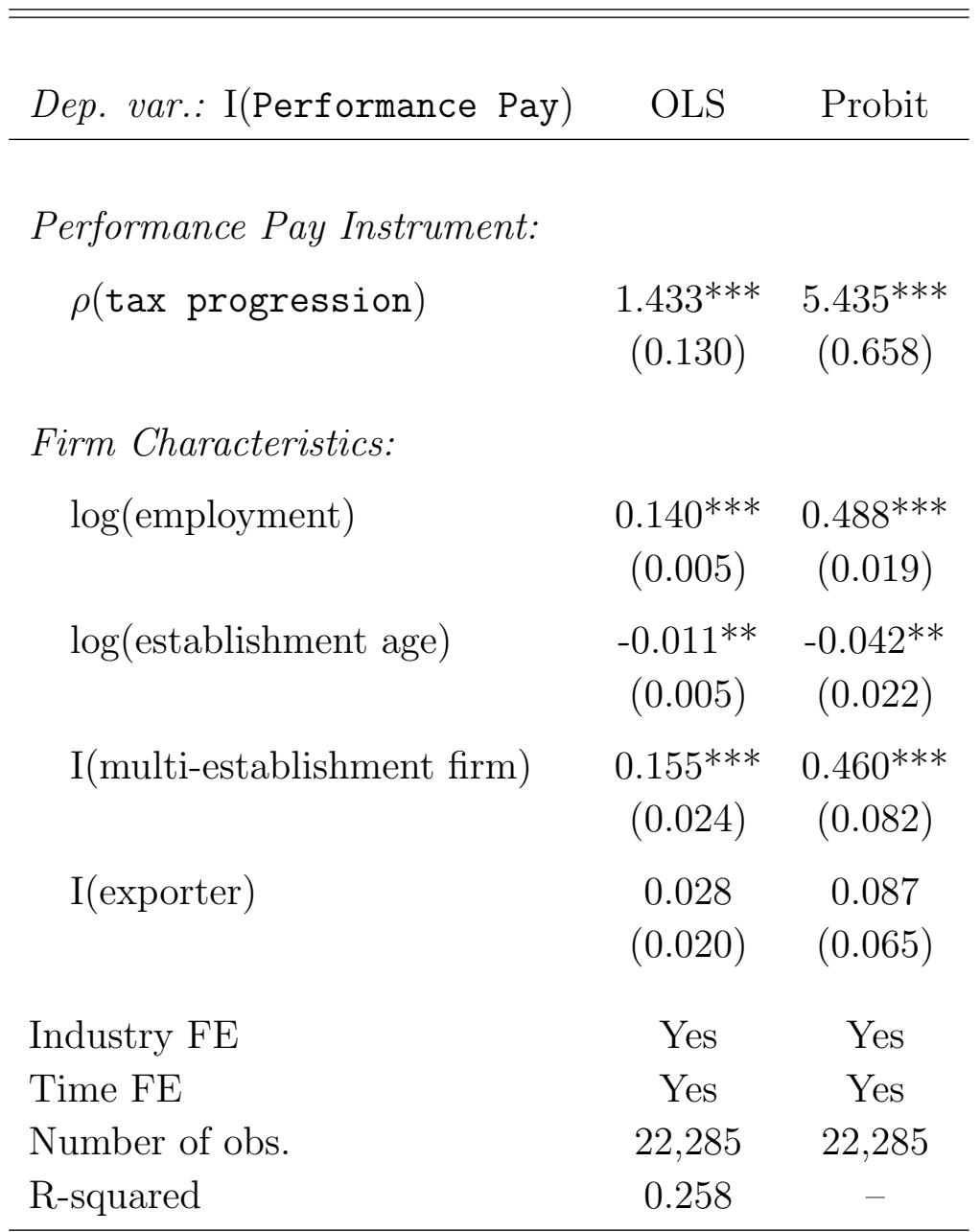

Notes: The measure of tax progression is residual income progression as defined in the text, where tax region is defined to be the location of the headquarters. Industry fixed effects are at the 4-digit NAICS level. Data is for years 1999, 2001, 2003, and 2005. Standard errors are clustered by region and year. All regressions use sampling weights. Results for first stage using only 2003 and 2005 are similar: the tax progression measure enters with a highly significant coefficient of 1.415 with a standard error of (0.24). The Craig-Donald F-statistic to test for weak IVs has a value of 249.05. 
Table 4: Decentralization and performance pay

\begin{tabular}{|c|c|c|c|c|c|c|}
\hline \multirow[b]{2}{*}{ Dep. var.: Control by } & \multicolumn{3}{|c|}{ OLS } & \multicolumn{3}{|c|}{ IV } \\
\hline & Principal & Manager & NonManager & Principal & Manager & NonManager \\
\hline \multicolumn{7}{|l|}{ Performance Pay Adoption: } \\
\hline I(Performance Pay) & $\begin{array}{c}-1.943^{* * *} \\
(0.359)\end{array}$ & $\begin{array}{c}0.892^{* * *} \\
(0.191)\end{array}$ & $\begin{array}{c}0.049 \\
(0.089)\end{array}$ & $\begin{array}{c}-5.838^{* * *} \\
(1.128)\end{array}$ & $\begin{array}{c}5.290^{* * *} \\
(1.187)\end{array}$ & $\begin{array}{c}-1.966^{* * *} \\
(0.733)\end{array}$ \\
\hline \multicolumn{7}{|l|}{ Firm Characteristics: } \\
\hline $\log ($ employment $)$ & $\begin{array}{c}-1.749 * * * \\
(0.119)\end{array}$ & $\begin{array}{c}0.622^{* * *} \\
(0.095)\end{array}$ & $\begin{array}{c}-0.134^{* *} \\
(0.052)\end{array}$ & $\begin{array}{c}-1.192^{* * *} \\
(0.210)\end{array}$ & $\begin{array}{c}0.000 \\
(0.124)\end{array}$ & $\begin{array}{c}0.147 \\
(0.121)\end{array}$ \\
\hline $\log ($ establishment age $)$ & $\begin{array}{c}0.042 \\
(0.090)\end{array}$ & $\begin{array}{c}0.020 \\
(0.097)\end{array}$ & $\begin{array}{c}0.065^{*} \\
(0.033)\end{array}$ & $\begin{array}{c}-0.096^{*} \\
(0.058)\end{array}$ & $\begin{array}{c}0.141^{* * *} \\
(0.043)\end{array}$ & $\begin{array}{c}0.007 \\
(0.037)\end{array}$ \\
\hline I(multi-establishment firm) & $\begin{array}{l}-0.343 \\
(0.236)\end{array}$ & $\begin{array}{c}-0.646^{* * *} \\
(0.248)\end{array}$ & $\begin{array}{c}-0.329 * * * \\
(0.114)\end{array}$ & $\begin{array}{c}0.353 \\
(0.252)\end{array}$ & $\begin{array}{c}-1.427^{* * *} \\
(0.292)\end{array}$ & $\begin{array}{c}0.008 \\
(0.162)\end{array}$ \\
\hline $\mathrm{I}$ (exporter) & $\begin{array}{c}0.383 \\
(0.323)\end{array}$ & $\begin{array}{c}-0.373^{* *} \\
(0.187)\end{array}$ & $\begin{array}{c}0.064 \\
(0.084)\end{array}$ & $\begin{array}{c}0.348 \\
(0.269)\end{array}$ & $\begin{array}{c}-0.402^{* *} \\
(0.197)\end{array}$ & $\begin{array}{c}0.036 \\
(0.143)\end{array}$ \\
\hline Industry FE & Yes & Yes & Yes & Yes & Yes & Yes \\
\hline Time FE & Yes & Yes & Yes & Yes & Yes & Yes \\
\hline Number of obs. & 11,684 & 11,684 & 11,684 & 11,684 & 11,684 & 11,684 \\
\hline R-squared & 0.355 & 0.255 & 0.186 & - & - & - \\
\hline 1st-stage F-stat. & n.a. & n.a. & n.a. & 34.61 & 34.61 & 34.61 \\
\hline
\end{tabular}


Table 5: IV regressions - inspecting the mechanism

\begin{tabular}{|c|c|c|c|c|c|c|}
\hline A. Occupation composition & managers & prod. workers & $\begin{array}{l}\text { Fraction of } \\
\text { professionals }\end{array}$ & sales rep. & admin. staff & \\
\hline I(Performance Pay) & $\begin{array}{c}0.300 * * * \\
(0.060)\end{array}$ & $\begin{array}{c}-0.233^{* * *} \\
(0.090)\end{array}$ & $\begin{array}{c}0.046^{*} \\
(0.027)\end{array}$ & $\begin{array}{c}0.014 \\
(0.038)\end{array}$ & $\begin{array}{l}-0.007 \\
(0.027)\end{array}$ & \\
\hline \multicolumn{7}{|c|}{ Rate of } \\
\hline B. Hiring and firing & layoffs & quits & dismissals & hiring & & \\
\hline I(Performance Pay) & $\begin{array}{l}-0.139 \\
(0.100)\end{array}$ & $\begin{array}{c}0.029 \\
(0.088)\end{array}$ & $\begin{array}{l}-0.002 \\
(0.040)\end{array}$ & $\begin{array}{l}-0.123 \\
(0.162)\end{array}$ & & \\
\hline C. Hiring by occupation & managers & prod. workers & professionals & sales rep. & admin. staff & \\
\hline I(Performance Pay) & $\begin{array}{c}0.039^{* *} \\
(0.017)\end{array}$ & $\begin{array}{c}-0.230^{* *} \\
(0.091)\end{array}$ & $\begin{array}{c}0.009 \\
(0.013)\end{array}$ & $\begin{array}{c}0.124^{* * *} \\
(0.047)\end{array}$ & $\begin{array}{l}-0.001 \\
(0.024)\end{array}$ & \\
\hline D. Organizational change & decentralize & re-engineer & downsize & adopt TQM & outsource & delayer \\
\hline I(Performance Pay) & $\begin{array}{l}-0.017 \\
(0.031)\end{array}$ & $\begin{array}{c}0.334^{* * *} \\
(0.066)\end{array}$ & $\begin{array}{c}0.026 \\
(0.054)\end{array}$ & $\begin{array}{c}0.183^{* * *} \\
(0.062)\end{array}$ & $\begin{array}{l}0.184^{*} \\
(0.100)\end{array}$ & $\begin{array}{c}0.063^{* * *} \\
(0.023)\end{array}$ \\
\hline Firm characteristics & Yes & Yes & Yes & Yes & Yes & Yes \\
\hline Industry FE & Yes & Yes & Yes & Yes & Yes & Yes \\
\hline Time FE & Yes & Yes & Yes & Yes & Yes & Yes \\
\hline Number of obs. & 22,285 & 22,285 & 22,285 & 22,285 & 22,285 & 22,285 \\
\hline
\end{tabular}

Notes: The specification is a LIML IV estimator with tax progression as instrument and the linear probability first stage displayed in table 3. Industry fixed effects are at the 4-digit NAICS level. Firm characteristics include log employment and log establishment age as well as indicators for multi-establishment firms and exporters. Years are 1999, 2001, 2003, and 2005. Standard errors are clustered by region and year. All regressions use sampling weights. 
Table 6: Robustness: Within-province and industry-interaction IVs

\begin{tabular}{|c|c|c|c|c|c|c|}
\hline \multirow[b]{2}{*}{ Dep. var.: Control by } & \multicolumn{3}{|c|}{ within-province } & \multicolumn{3}{|c|}{ industry-interaction IV } \\
\hline & Principal & Manager & NonManager & Principal & Manager & NonManager \\
\hline \multicolumn{7}{|l|}{ Performance Pay Adoption: } \\
\hline I(Performance Pay) & $\begin{array}{c}-8.495^{* * *} \\
(2.089)\end{array}$ & $\begin{array}{l}3.225^{*} \\
(1.918)\end{array}$ & $\begin{array}{c}-1.975^{* *} \\
(0.925)\end{array}$ & $\begin{array}{c}-5.573^{* * *} \\
(1.378)\end{array}$ & $\begin{array}{c}4.747^{* * *} \\
(1.459)\end{array}$ & $\begin{array}{c}-1.900^{* *} \\
(0.743)\end{array}$ \\
\hline \multicolumn{7}{|l|}{ Firm Characteristics: } \\
\hline $\log ($ employment $)$ & $\begin{array}{l}-0.105 \\
(0.247)\end{array}$ & $\begin{array}{c}0.315 \\
(0.320)\end{array}$ & $\begin{array}{c}0.023 \\
(0.102)\end{array}$ & $\begin{array}{c}-1.229^{* * *} \\
(0.224)\end{array}$ & $\begin{array}{c}0.075 \\
(0.188)\end{array}$ & $\begin{array}{c}0.137 \\
(0.110)\end{array}$ \\
\hline $\log ($ establishment age $)$ & $\begin{array}{c}0.419 \\
(0.327)\end{array}$ & $\begin{array}{l}-0.221 \\
(0.306)\end{array}$ & $\begin{array}{c}-0.007 \\
(0.083)\end{array}$ & $\begin{array}{c}-0.088 \\
(0.086)\end{array}$ & $\begin{array}{c}0.124 \\
(0.077)\end{array}$ & $\begin{array}{c}0.009 \\
(0.045)\end{array}$ \\
\hline I(multi-establishment firm) & $\begin{array}{c}-1.448^{* * *} \\
(0.364)\end{array}$ & $\begin{array}{l}-0.126 \\
(0.646)\end{array}$ & $\begin{array}{c}-0.299 \\
(0.279)\end{array}$ & $\begin{array}{c}0.306 \\
(0.412)\end{array}$ & $\begin{array}{c}-1.330^{* * *} \\
(0.305)\end{array}$ & $\begin{array}{c}-0.004 \\
(0.165)\end{array}$ \\
\hline $\mathrm{I}$ (exporter) & $\begin{array}{c}0.772 \\
(0.569)\end{array}$ & $\begin{array}{l}-0.464 \\
(0.587)\end{array}$ & $\begin{array}{c}0.048 \\
(0.173)\end{array}$ & $\begin{array}{c}0.349 \\
(0.296)\end{array}$ & $\begin{array}{c}-0.403^{* *} \\
(0.201)\end{array}$ & $\begin{array}{c}0.036 \\
(0.126)\end{array}$ \\
\hline Industry FE & Yes & Yes & Yes & Yes & Yes & Yes \\
\hline Time FE & Yes & Yes & Yes & Yes & Yes & Yes \\
\hline Province FE & Yes & Yes & Yes & No & No & No \\
\hline Number of obs. & 1,540 & 1,540 & 1,540 & 11,684 & 11,684 & 11,684 \\
\hline
\end{tabular}

Notes: OLS-columns use dummy for performance pay as independent variable. IV-columns use a LIML IV estimator with tax progression as instrument and the linear probability first stage displayed in table 3. Years are 2003 and 2005 as information distinguishing business owners from senior management is only available in these years. Standard errors are clustered by sampling strata for OLS, which are broad industry-size-region categories. Clustering for IV is by region and year. All regressions use sampling weights. The dependent variables are number of decisions made by principals, management, and non-managerial employees. 
Table 7: Robustness: Alternative mechanisms-Principal

\begin{tabular}{|c|c|c|c|c|c|c|c|c|}
\hline \multirow[b]{2}{*}{ I(Performance Pay) } & \multicolumn{8}{|c|}{ Dependent variable: Control Principal } \\
\hline & $\begin{array}{c}-5.630^{* * *} \\
(1.125)\end{array}$ & $\begin{array}{c}-5.661^{* * *} \\
(1.125)\end{array}$ & $\begin{array}{c}-6.227^{* * *} \\
(0.952)\end{array}$ & $\begin{array}{c}-5.212^{* * *} \\
(1.360)\end{array}$ & $\begin{array}{c}-5.569^{* * *} \\
(1.093)\end{array}$ & $\begin{array}{c}-5.369^{* * *} \\
(0.855)\end{array}$ & $\begin{array}{c}-8.630^{* * *} \\
(1.828)\end{array}$ & $\begin{array}{c}-7.640^{* * *} \\
(1.573)\end{array}$ \\
\hline I(local competition) & & $\begin{array}{c}0.047 \\
(0.133)\end{array}$ & & & & & & $\begin{array}{c}0.168 \\
(0.196)\end{array}$ \\
\hline Task scope & & & $\begin{array}{c}0.788^{* * *} \\
(0.035)\end{array}$ & & & & & $\begin{array}{c}0.732^{* * *} \\
(0.037)\end{array}$ \\
\hline No. of decision layers & & & $\begin{array}{c}-1.294^{* * *} \\
(0.152)\end{array}$ & & & & & $\begin{array}{c}-1.139^{* * *} \\
(0.167)\end{array}$ \\
\hline Average wage & & & & $\begin{array}{c}-0.012^{* *} \\
(0.005)\end{array}$ & & & & $\begin{array}{l}-0.002 \\
(0.005)\end{array}$ \\
\hline Fraction of top earners & & & & $\begin{array}{c}1.978 * * \\
(0.886)\end{array}$ & & & & $\begin{array}{c}2.498 * * \\
(1.016)\end{array}$ \\
\hline I(novelty as top stgy.) & & & & & $\begin{array}{c}0.228 \\
(0.260)\end{array}$ & & & $\begin{array}{c}0.540^{*} \\
(0.323)\end{array}$ \\
\hline Std(operating margin) & & & & & & $\begin{array}{c}42.844 \\
(37.670)\end{array}$ & & $\begin{array}{c}23.482 \\
(30.031)\end{array}$ \\
\hline I(Quebec) & & & & & & & $\begin{array}{c}-0.826^{* * *} \\
(0.213)\end{array}$ & $\begin{array}{c}-0.490^{*} \\
(0.276)\end{array}$ \\
\hline Firm characteristics & Yes & Yes & Yes & Yes & Yes & Yes & Yes & Yes \\
\hline Industry $\times$ Time FE & Yes & Yes & Yes & Yes & Yes & Yes & Yes & Yes \\
\hline Number of obs. & 11,684 & 11,605 & 11,684 & 11,602 & 11,684 & 11,442 & 11,684 & 11,301 \\
\hline
\end{tabular}

Notes: The dependent variable is the number of decisions made by principals. The main controls capture various alternative mechanisms and are discussed in the main text. The IV specification is a LIML estimator with tax progression as instrument and the linear probability first stage displayed in table 3. Firm characteristics include log employment and log establishment age as well as indicators for multi-establishment firms and exporters. Years are 2003 and 2005 as information distinguishing business owners from senior management is only available in these years. Standard errors are clustered by region and year. All regressions use sampling weights. 
Table 8: Robustness: Alternative mechanisms-Management

\begin{tabular}{|c|c|c|c|c|c|c|c|c|}
\hline \multirow[b]{2}{*}{ I(Performance Pay) } & \multicolumn{8}{|c|}{ Dependent variable: Control ${ }^{\text {Manager }}$} \\
\hline & $\begin{array}{c}5.140^{* * *} \\
(1.012)\end{array}$ & $\begin{array}{c}5.141^{* * *} \\
(1.002)\end{array}$ & $\begin{array}{c}4.878^{* * *} \\
(0.833)\end{array}$ & $\begin{array}{c}5.288^{* * *} \\
(1.128)\end{array}$ & $\begin{array}{c}5.047^{* * *} \\
(0.949)\end{array}$ & $\begin{array}{c}5.006^{* * *} \\
(1.037)\end{array}$ & $\begin{array}{c}6.276^{* * *} \\
(1.990)\end{array}$ & $\begin{array}{c}5.697^{* * *} \\
(1.675)\end{array}$ \\
\hline I(local competition) & & $\begin{array}{c}-0.295^{* *} \\
(0.121)\end{array}$ & & & & & & $\begin{array}{c}-0.324^{* *} \\
(0.150)\end{array}$ \\
\hline Task scope & & & $\begin{array}{c}0.257^{* * *} \\
(0.040)\end{array}$ & & & & & $\begin{array}{c}0.290^{* * *} * \\
(0.046)\end{array}$ \\
\hline No. of decision layers & & & $\begin{array}{c}-0.741^{* * *} \\
(0.171)\end{array}$ & & & & & $\begin{array}{c}-0.833^{* * *} \\
(0.213)\end{array}$ \\
\hline Average wage & & & & $\begin{array}{c}-0.003 \\
(0.003)\end{array}$ & & & & $\begin{array}{c}0.000 \\
(0.004)\end{array}$ \\
\hline Fraction of top earners & & & & $\begin{array}{c}-0.887 \\
(0.686)\end{array}$ & & & & $\begin{array}{c}-1.273^{*} \\
(0.731)\end{array}$ \\
\hline I(novelty as top stgy.) & & & & & $\begin{array}{l}-0.345 \\
(0.314)\end{array}$ & & & $\begin{array}{c}-0.271 \\
(0.352)\end{array}$ \\
\hline Std(operating margin) & & & & & & $\begin{array}{c}78.294^{* * * *} \\
(24.843)\end{array}$ & & $\begin{array}{c}76.689^{* * *} \\
(24.466)\end{array}$ \\
\hline I(Quebec) & & & & & & & $\begin{array}{c}0.313 \\
(0.265)\end{array}$ & $\begin{array}{c}0.300 \\
(0.235)\end{array}$ \\
\hline Firm characteristics & Yes & Yes & Yes & Yes & Yes & Yes & Yes & Yes \\
\hline Industry $\times$ Time FE & Yes & Yes & Yes & Yes & Yes & Yes & Yes & Yes \\
\hline Number of obs. & 11,684 & 11,605 & 11,684 & 11,602 & 11,684 & 11,442 & 11,684 & 11,301 \\
\hline
\end{tabular}

Notes: The dependent variable is the number of decisions made by managerial employees. The main controls capture various alternative mechanisms and are discussed in the main text. The IV specification is a LIML estimator with tax progression as instrument and the linear probability first stage displayed in table 3. Firm characteristics include log employment and log establishment age as well as indicators for multi-establishment firms and exporters. Years are 2003 and 2005 as information distinguishing business owners from senior management is only available in these years. Standard errors are clustered by region and year. All regressions use sampling weights. 
Table 9: Robustness: Alternative mechanisms-Non-Management

\begin{tabular}{|c|c|c|c|c|c|c|c|c|}
\hline \multirow[b]{2}{*}{ I(Performance Pay) } & \multicolumn{8}{|c|}{ Dependent variable: Control ${ }^{\text {NonManager }}$} \\
\hline & $\begin{array}{c}-2.011^{* * *} \\
(0.668)\end{array}$ & $\begin{array}{c}-2.023^{* * *} \\
(0.679)\end{array}$ & $\begin{array}{c}-1.912^{* * *} \\
(0.606)\end{array}$ & $\begin{array}{c}-2.184^{* * *} \\
(0.728)\end{array}$ & $\begin{array}{c}-1.992^{* * *} \\
(0.637)\end{array}$ & $\begin{array}{c}-1.984^{* * *} \\
(0.649)\end{array}$ & $\begin{array}{c}-3.669^{* * *} \\
(1.186)\end{array}$ & $\begin{array}{c}-3.909^{* * *} \\
(1.220)\end{array}$ \\
\hline I(local competition) & & $\begin{array}{c}0.017 \\
(0.048)\end{array}$ & & & & & & $\begin{array}{c}0.111 \\
(0.077)\end{array}$ \\
\hline Task scope & & & $\begin{array}{c}-0.011 \\
(0.018)\end{array}$ & & & & & $\begin{array}{c}-0.036 \\
(0.028)\end{array}$ \\
\hline No. of decision layers & & & $\begin{array}{c}0.445^{* * *} \\
(0.070)\end{array}$ & & & & & $\begin{array}{c}0.598 * * * \\
(0.116)\end{array}$ \\
\hline Average wage & & & & $\begin{array}{c}0.006^{* * *} \\
(0.002)\end{array}$ & & & & $\begin{array}{c}0.006^{* *} \\
(0.003)\end{array}$ \\
\hline Fraction of top earners & & & & $\begin{array}{c}0.158 \\
(0.316)\end{array}$ & & & & $\begin{array}{c}0.769^{*} \\
(0.426)\end{array}$ \\
\hline I(novelty as top stgy.) & & & & & $\begin{array}{c}0.070 \\
(0.142)\end{array}$ & & & $\begin{array}{c}0.213 \\
(0.204)\end{array}$ \\
\hline Std(operating margin) & & & & & & $\begin{array}{c}-38.714^{* *} \\
(17.316)\end{array}$ & & $\begin{array}{l}-36.589 \\
(26.874)\end{array}$ \\
\hline I(Quebec) & & & & & & & $\begin{array}{c}-0.457^{* * *} \\
(0.152)\end{array}$ & $\begin{array}{c}-0.547^{* * *} \\
(0.178)\end{array}$ \\
\hline Firm characteristics & Yes & Yes & Yes & Yes & Yes & Yes & Yes & Yes \\
\hline Industry $\times$ Time FE & Yes & Yes & Yes & Yes & Yes & Yes & Yes & Yes \\
\hline Number of obs. & 11,684 & 11,605 & 11,684 & 11,602 & 11,684 & 11,442 & 11,684 & 11,301 \\
\hline
\end{tabular}

Notes: The dependent variable is the number of decisions made by non-managerial employees. The main controls capture various alternative mechanisms and are discussed in the main text. The IV specification is a LIML estimator with tax progression as instrument and the linear probability first stage displayed in table 3. Firm characteristics include log employment and log establishment age as well as indicators for multi-establishment firms and exporters. Years are 2003 and 2005 as information distinguishing business owners from senior management is only available in these years. Standard errors are clustered by region and year. All regressions use sampling weights. 